\title{
Intellectual Property Right of Transgenic Crops and Right to Work: Bioethical Challenges in Rural Communities
}

\author{
Bahareh Heydari ${ }^{1}$, Najmeh Razmkhah ${ }^{2}$ \\ ${ }^{1}$ Assistant Professor, Department of Law, Payame Noor University, Tehran, I.R. of Iran. \\ ${ }^{2}$ Lecturer, Department of Law, Payame Noor University, Tehran, I.R. of Iran. \\ Email: baharheydari@yahoo.com; najmehrazmkhah@yahoo.com
}

\begin{abstract}
Increasing importance of intellectual property rights (IPR) over the area of seed production, is radically transforming agricultural production relations. One major effect of this transformation is the exclusive control of biotech companies on process of transaction of GM crops. This new status, that is the part of a trend that was set in national and international documents to protect inventors, may have adverse impact on the right to work of poor and vulnerable farmers in developing countries. In the framework of international human rights, the right to work is the fundamental right of every one to have sustainable access to decent work that meets the needs and welfare of his livelihood. Rural communities enjoy this right similar to the urban communities. But, the main question, which is our major concern, is the relationship between IPR and the right to work with attention to articles of International Covenant on Economic, Social and Cultural right and International Treaty on Plant Genetic Resources for Food and Agriculture.
\end{abstract}

Keywords: Biotechnology, Genetically modified seeds, Intellectual Property Right (IPR), Rural communities, Right to work, International Covenant on Economic, Social and Cultural right, International Treaty on Plant Genetic Resources for Food and Agriculture

Introduction: Labor is one of the basic necessities for survival of mankind. Human being is social and attempts to work, despite the variety of collections, ecology, and diversity in the pace of technical progress and the evolution of social and economic construction. The work is a necessary condition of human life in society. Work fundamentally changes the nature. Human beings use technology to create an effect on other human beings and nature. Marx wrote in his classic book entitled Capital: "At first glance, work is the interaction that occurs between man and nature."

International Labor Organization (ILO), as one of the specialized agencies of the United Nations has consistently emphasized that labor is not a commodity. Unemployment causes poverty, and poverty anywhere is a threat to public welfare. Therefore, the fight against poverty at the national and international level is necessary. Secretary-General of the ILO considers decent work as a 
concept in creating equal opportunities for women and men to achieve appropriate and productive work in conditions of freedom and security, with dignity. In the framework of international law, the right to work has been recognized as a fundamental right of every person to benefit from the opportunity to earn a living by work which must be chosen or accepted freely.

The legal basis for the right to work is Article 6 of the International Covenant on Economic, Social and Cultural Rights (hereafter covenant), which says:" The States Parties to the present Covenant recognize the right to work, which includes the right of everyone to the opportunity to gain his living by work which he freely chooses or accepts, and will take appropriate steps to safeguard this right."

In the second paragraph of this article it is emphasized that "The steps to be taken by a State Party to the present Covenant to achieve the full realization of this right shall include technical and vocational guidance and training programmes, policies and techniques to achieve steady economic, social and cultural development and full and productive employment under conditions safeguarding fundamental political and economic freedoms to the individual". In addition to the Covenant, the right to work as a concept of international human rights, has been emphasized in international instruments on human rights, such as Universal Declaration of Human Rights, the Convention on the Elimination of All Forms of Discrimination against Women. Committee on economic, social and cultural rights (hereafter committee) in general comment No. 18 considers that: "The right to work is essential for realizing other human rights and forms an inseparable and inherent part of human dignity. Every individual has the right to be able to work, allowing him/her to live in dignity. The right to work contributes at the same time to the survival of the individual and to that of his/her family, and insofar as work is freely chosen or accepted, to his/her development and recognition within the community." However, human rights activists often have expressed concern about the ignorance of the rights of communities, especially rural communities.

With the adventure of new technologies and introduction of transgenic seeds to farmers, various questions on risk factors have been raised by many authors, e.g. problems related consequences of IP on right to work of villagers. Because rural work primarily is based on agriculture, and biotech Patents by large companies lead farmers to depend on these companies, to bear the high costs to buy the crops which they need, therefore poor villagers because of high expenditure are removed from the work market and this means the violation of the farmer's right to work. Consequently, this article will attempt to review the terms and provisions contained in the instruments of international law, the obligations of States in relation to the right to work and describe the impact of patent of transgenic seeds on this right. 
To this end, at first the situation of right to work in international instrument of human rights has been described, second, the obligation of governments about this right and then negative effects of IP of GM crops on the right to work in rural communities have been discussed. Finally, at the end of the article conclusions and recommendations from the study will be presented.

Transgenic crops: Transgenic organisms, also called Genetically Modified Organisms (GMO), are generally produced by applying the techniques of genetic engineering or modification of genetic materials of crops 1 . The modification can most simply be defined as the transfer of genetic material from a different species or from a chemically synthesized gene in to a target plant. The first successful genetic engineering of a plant was reported in 1983. Biotechnologization of agriculture represent the ongoing attempts to transform agriculture through the commercial deployment of biotechnological innovations, as a result of newly acquired insights in molecular biology and genetic, and, in turn, development of technological products and processes based on living organisms for collectively described as biotechnology ${ }^{2}$. Geneticallymodified (GM) seeds are a significant step forward in the production of agricultural crops. GM seeds are seeds that have been modified to contain specific characteristics such as resistance to herbicides (in the case of "Roundup Ready" products) or resistance to pests (in the case of Bt corn) $)^{3}$.

Right to work: Work is essential for every body in the organization of contemporary society. It not only contributes to the formation of the individual, but it is also necessary if one is to be able to support oneself and his family, make and keep social contacts and fulfill his or her duties toward society ${ }^{4}$.

The importance of work and productive employment in any society is not only because of the resources which they create for the community, but also because of the income which they bring to workers, the social role which they confer and the feeling of self-esteem which workers derive from them. The right to work is an individual right that belongs to each person and is at the sometime a collective right. It encompasses all forms of work, whether independent work or dependent wage-paid work and is essential for realizing other human rights and forms an inseparable and inherent part of human dignity. Every individual has the right to be able to work, allowing him/her to live in dignity. The right to work contributes at the same time to the survival of the individual and to that of his/her family, and insofar as work is freely chosen or accepted, to his/her development and recognition within the community. Covenant as laid down in article 6, deals more comprehensively than any other instrument with this right: " The States Parties to the present Covenant recognize the right to work, which includes the right of everyone to the opportunity to gain his living by work which he freely chooses or accepts, and will take 
appropriate steps to safeguard this right. " The exercise of work in all its forms and at all levels requires the existence of the following interdependent and essential elements, implementation of which will depend on the conditions present in each State party:

(a) Availability. States parties must have specialized services to assist and support individuals in order to enable them to identify and find available employment.

(b) Accessibility. The labor market must be open to everyone under the jurisdiction of States parties.

\section{International Obligations of Governments in field of Right to Work}

1. The status of Right to Work in International Instruments on Human Rights: Unlike negligence about right to work in practice, much attention has been focused in theory on this right. ILO Constitution and Declaration of Philadelphia, which demonstrates the organization's goal, without mentioning the term " right to work ", relying on the principle that human labor should not be regarded as a commodity, on the endorse the fact that working does not itself, this is the man who works, work is part of his personality. For the first time right to work were cited in Article 55 of UN Charter: " With a view to the creation of conditions of stability and well-being which are necessary for peaceful and friendly relations among nations based on respect for the principle of equal rights and self - determination of peoples, the United Nations shall promote: "A higher standards of living, full employment, and conditions of economic and social progress and development".

Under paragraph 1 of Article 23 of the Universal Declaration of Human Right:" Everyone has the right to work, to free choice of employment, to just and favorable conditions of work and to protection against unemployment ". Universal Declaration of Human Right has been accepted such an extent that many lawyers believe that at least a certain portion of its contents have arrived into customary international law. Even if you reject this theory, this matter could not be denied the higher position of declaration on any other legal soft law ${ }^{5}$.

Apart from the basic documents on human rights in the context of many other international human rights instruments, the right to work is mentioned including, the first paragraph of article 11 of the Convention on Elimination of all Forms of Discrimination against Women, article 18 of the Convention relating to the Status of Refugees, which deals with the issue of employment in non-government, article 15 of African Charter on Human and Peoples, Right ( Banjul Charter), first and second paragraphs of article II of section 2 of Europe Social Charter and the article 7 of Additional Protocol to the American Convention on Human Rights, the Law on Economic , Social and Cultural (Protocol of San Salvador). 
2. States and Actors other than states parties' obligations to Right to Work: The principal obligation of States parties is to ensure the progressive realization of the exercise of the right to work. States parties must therefore adopt, as quickly as possible, measures aiming at achieving full employment. While the Covenant provides for progressive realization and acknowledges the constraints due to the limits of available resources, it also imposes on States parties various obligations which are of immediate effect. 11 States parties have immediate obligations in relation to the right to work, such as the obligation to guarantee that it will be exercised "without discrimination of any kind and the obligation "to take steps" towards the full realization of article 6.12 Such steps must be deliberate, concrete and targeted towards the full realization of the right to work.

Like all human rights, the right to work imposes three types or levels of obligations on States parties: the obligations to respect protect and fulfill. The obligation to respect the right to work requires States parties to refrain from interfering directly or indirectly with the enjoyment of that right. The obligation to protect requires States parties to take measures that prevent third parties from interfering with the enjoyment of the right to work. The obligation to fulfill includes the obligations to provide, facilitate and promote that right. It implies that States parties should adopt appropriate legislative, administrative, budgetary, judicial and other measures to ensure its full realization.

In its general comment No. 3 (1990), the Committee draws attention to the obligation of all States parties to take steps individually and through international assistance and cooperation, especially economic and technical, towards the full realization of the rights recognized in the Covenant. In the spirit of Article 56 of the Charter of the United Nations and specific provisions of the Covenant (arts. 2.1, 6, 22 and 23), States parties should recognize the essential role of international cooperation and comply with their commitment to take joint and separate action to achieve the full realization of the right to work. States parties should, through international agreements where appropriate, ensure that the right to work as set forth in articles 6,7 and 8 of the Covenant is given due attention.

To comply with their international obligations in relation to article 6, States parties should endeavor to promote the right to work in other countries as well as in bilateral and multilateral negotiations. In negotiations with international financial institutions, States parties should ensure protection of the right to work of their population. States parties that are members of international financial institutions, in particular the International Monetary Fund, the World Bank and regional development banks, should pay greater attention to the protection of the right to work in influencing the lending policies, credit agreements, structural adjustment programmes and 
international measures of these institutions. The strategies, programmes and policies adopted by States parties under structural adjustment programmes should not interfere with their core obligations in relation to the right to work and impact negatively on the right to work of women, young persons and the disadvantaged and marginalized individuals and groups.

While only States are parties to the Covenant and are thus ultimately accountable for compliance with it, all members of society, individuals, local communities, trade unions, civil society and private sector organizations have responsibilities regarding the realization of the right to work. States parties should provide an environment facilitating the discharge of these obligations. Private enterprises - national and multinational - while not bound by the Covenant, have a particular role to play in job creation, hiring policies and non-discriminatory access to work. They should conduct their activities on the basis of legislation, administrative measures, codes of conduct and other appropriate measures promoting respect for the right to work, agreed between the governments and civil society. Such measures should recognize the labor standards elaborated by ILO and aim at increasing the awareness and responsibility of enterprises in the realization of the right to work. According to the committee interpretation, governments and nongovernmental commercial organizations are obliged to respect this right.

Governments at the national and international levels have a duty to take all necessary measures in order to provide people with the opportunity to enjoy the right to work and remove obstacles in the implementation of this right and of course, apply necessary regulations on commercial activities, to prevent violation of the right of people to work. Another significant point is that neither the Covenant nor the committee's interpretation has been addressed special resolution based on the nature of the work. Therefore farmers and the agricultural sector have been subject to the rights which provided by international documents, so governments are committed towards them to provide and ensure the right to work on all three levels. But in practice the situation is not quite as good and nowadays, the poor condition of the employment in rural communities has become one of the human rights activists concerns. An issue that has not attracted much attention at the international level, so at any time speak of the right to work, employment in urban communities comes to mind. Thus it has been neglected by governments and non governmental organizations such as Biotech companies. Evidence for this claim is a condition in which the transgenic seeds have been sold to farmers in less developed countries which has become a serious challenge in communities, especially in less developed countries, where most farmers are poor and vulnerable part of society.

The next section according to the provisions of the international instruments describes these problems and legal issues arising from the conflict between the IP of Biotech companies and farmers right to work. 


\section{IPR of GM Crops and Right to Work of Farmers}

1. Negative effects arising from the IPR on the labor market in rural communities: Perhaps the most contentious issue related to biotechnology today is that of intellectual property rights (IPRs). IPRs in general terms, allow developers of GMOs to patent a new transgenic variety and claim exclusive rights to that product, making it illegal for use in the countries where a patent is awarded without the user's agreement to meet conditions imposed by company. In many cases, these conditions include payment of a 'technology fee' (to help cover the research and development investment) and signing a contract pledging not to save, replant, or sell the seeds from crops grown with the patented seed 6. Patenting living organisms is a recent legal development that causes concern for a number of reasons. One potential result of patenting transgenic plant varieties is the effective criminalization of centuries old agricultural practices such as seed selection, saving, and sharing. Historically, farmers themselves have been the major innovators in agriculture, developing superior crops through their own selection processes. In the 1990s, 80 percent of crops planted in developing countries were sown from farm-saved seeds. With patented seeds, farmers' ability to save seeds for future planting is constricted and dependence on large multi-national companies increases because farmers must buy new seeds every season ${ }^{7}$.

In many communities, seeds also serve as a type of social capital, and sharing seeds provides a basis for interdependence among farmers within a community. If patented GM seeds become commonplace, the possibility exists for behaviors that form the backbone of traditional agriculture, such as seed-sharing, to become illegal, thereby eroding farming communities themselves ${ }^{8}$.

The contracts of seed companies require that buyers of their GM seeds sign when obtaining those seeds may disadvantage farmers. Seed companies have invested significant funds in the research and development of GM seeds, and they protect this investment through their contracts with agricultural growers. These contracts aggressively protect the biotechnology company's rights to the seeds, frame the context within which disputes may be settled, and limit the liability of the company. Under a private contract between a grower and a biotech company, the $\mathrm{g}$ rower's rights to the purchased seed are significantly limited. Such contracts generally contain a "no saved seed" provision. This provision prohibits growers from saving seed and/or reusing seed from GM crops. In effect, the provision requires growers of GM crops to make an annual purchase of GM seeds ${ }^{9}$.

Contracts between seed companies and farmers sometimes contain a clause that limits the "liability of [the seed company] to or any seller for any and all losses, injury or damages resulting 
from the use or handling of a product containing [the seed company's] gene technology shall be the price paid by the grower for the quantity of such product involved, or at the election of [the seed company] or any seller, the replacement of such quantity. In no event shall [the seed company] or any seller be liable for any incidental, consequential, special or punitive damages. Under such a clause, if the use of GM seed has a negative impact on another aspect of the farmer's operations, this clause precludes the farmer from recovering any damages from the company in the event the use of the product causes harm ${ }^{10}$.

With this process, farmers have to pay for the use of seeds which are used and protected over the centuries, so the rural communities will expose to the risk of dependence of farmers with commercial suppliers of critical materials like seeds. On the other hand, most of these farmers could not compete with large farmers, so they forced to sell or lease their farms to rich farmers or biotech companies. These issues often lead to deprive poor and vulnerable farmers of their basic right to work. So farmers will be unemployed and their family well-being will be in trouble. This situation is not limited to violations of the right to work, because of interdependence between the fundamental principles of human rights: violation of one right can lead to dangerous consequences for rural communities.

2. Analysis the conflict between IPR of seeds and the right to work: As was discussed in the previous section, biotechnology companies as breeders of genetic manipulated and improved seeds on the base of legal sources, including the covenant and other supporting documents of intellectual property claim that they have exclusive right on these seeds. Problems in this regard and violation of farmers, right have been attracted the international community considerations. In this regard, the United Nation Food and Agriculture Organization (FAO) for the first time presented concept of "farmer's right". In this sense, the right of farmers and rural communities for the control, management, development and exploitation of plant genetic resources belong to them has been recognized and then International Treaty on Plant Genetic Resources for Food and Agriculture ( here after treaty), in order to afford greater attention to this right in the thirty-first FAO conference in 2001, was approved.

In the preamble of the treaty, farmers, right and plant breeders, rights have been identified as complement. So governments must accordance to their needs and priorities identify and reorganize these rights. Each member should take measures to protect and promote farmers, rights at national and international level to adopt the following measures: Protection of traditional knowledge relevant to plant genetic resources for food and agriculture, the right to equitable participation in sharing benefits from the use of plant genetic resources. 
In fact, this treaty was formulated to establish an independent legal system for protection of farmers, right and create balance between the rights of inventors and creation of new varieties of plants by IPR system and rights of farmers to reuse, sale and exchange of plant genetic resources.

Article 9 of the treaty, was developed with the title of farmers, right. Accordance to paragraph B of this article: " The Contracting Parties agree that the responsibility for realizing farmers, right, as they relate to plant genetic resources for food and agriculture, rests with national governments. In accordance with their needs and priorities, each contracting party should, as appropriate and subject to its national legislation, take measures to protect and promote farmers, right, including:

(a) Protection of traditional knowledge relevant to plant genetic resources for food and agriculture;

(b) The right to equitably participate in sharing benefits arising from the utilization of plant genetic resources for food and agriculture; and

(c) The right to participate in making decisions, at the national level, on matters related to the conservation and sustainable use of plant genetic resources for food and agriculture.

According to the third paragraph of article 9:" Nothing in this Article shall be interpreted to limit any rights that farmers have to save, use, exchange and sell farm-saved seed/propagating material, subject to national law and as appropriate". Another strong point of this treaty is a multilateral system of access and benefit sharing, which was included in part IV. Under the provisions of this section, the genetic material derived from 64 kinds of food and feed crops listed in Annex I to the treaty, is freely available to researchers, which in turn should share due benefits with other beneficiaries to these species.

The rights of farmers, without mentioning the name of the right to work, is shown of the provisions of this treaty, of course the content of article 9 can be useful in providing job security for farmers. Despite the points were raised, weaknesses can be seen in the treaty. In general, treaty is vague on the way of sharing benefits and how to determine the beneficiaries. In addition the content of treaty have been enacted in a way, which the biotech corporations, interests have priority over the interests of farmers. For example, in the seventh paragraph of the preamble clearly states that: "Affirming that nothing in this Treaty shall be interpreted as implying in any way a change in the rights and obligations of the Contracting Parties under other international agreements". Also in the sixth section of the third paragraph of Article 12 states that:"Access to plant genetic resources for food and agriculture protected by intellectual and other property rights shall be consistent with relevant international agreements and with relevant national laws". So in case of a conflict between the rights of farmers which has defined by article 9 and IPR which are supported by another agreements and national regulations, IPR will be preferred. On the other hand, in 
article 9 only farmers, right have been enumerated without anticipated specific enforcement of these rights. Because of disagreement between member states on how to implement this regulation exists, in practice it has been dropped. So the biotech companies relying on the other international agreements, including the covenant, exercise their IPR, and the rights of farmers have been ignored. Among the principles that have been invoked by biotech companies to apply their IPR is the article 15 of the covenant, therefore the analysis of this article and it's relationship with other articles such as article 6 of the covenant is necessary. The first paragraph of article 15 of the covenant declares that:

"1. The States Parties to the present Covenant recognize the right of everyone: (a) To take part in cultural life; (b) To enjoy the benefits of scientific progress and its applications; (c) To benefit from the protection of the moral and material interests resulting from any scientific, literary or artistic production of which he is the author."

As it could be seen, this paragraph contains three human rights and according to the statement it seems that the right to participate in cultural life, included the other two rights and in fact, is prerequisite for two other rights. Thus simultaneously confirms people,s right to benefit from scientific progress and IPR of scientists. The next important point is that, human rights principles are joined together, so articles of human rights instruments, including the covenant should not be without considering the other principles. For this reason, the Committee has brought out in paragraph 4 of Interpretation No. 17. "The right to benefit from the protection of the moral and material interests resulting from one's scientific, literary and artistic productions seeks to encourage the active contribution of creators to the arts and sciences and to the progress of society as a whole. As such, it is intrinsically linked to the other rights recognized in article 15 of the Covenant, i.e. the right to take part in cultural life (art. 15, para. 1, a), the right to enjoy the benefits of scientific progress and its applications (art. 15, para. 1, b), and the freedom indispensable for scientific research and creative activity (art. 15, para. 3). The relationship between these rights and article 15, paragraph 1 (c), is at the same time mutually reinforcing and reciprocally limitative. The limitations imposed on the right of authors to benefit from the protection of the moral and material interests resulting from their scientific, literary and artistic productions by virtue of these rights will partly be explored in this general comment, partly in separate general comments on article 15, paragraphs 1 (a) and (b) and 3, of the Covenant. As a material safeguard for the freedom of scientific research and creative activity, guaranteed under article 15, paragraph 3 and article 15, paragraph 1 (c), also has an economic dimension and is, therefore, closely linked to the rights to the opportunity to gain one's living by work which one freely chooses (art. 6, para. 1) and to adequate remuneration (art. 7, a), and to the human right to an adequate standard of living (art. 11, para. 1). 
So to interpret obligations arising from the article 15, other articles of covenant such as article 6 and two following points must be considered. First, it is a mistake to believe that always and in all circumstances, similar forms of support must be applied to individual or collective rights of people to enjoy the benefits of science and new technologies, because depending on different conditions and circumstances, this type of support may be desirable or not. Second, to interpret human right principles, more attention must be taken to poor and vulnerable communities. Thus while respect to IPR is necessary but because of expression of this right, the right to benefit of scientific progress and its applications, in one article, it can be said that IPR can be a tool to support the right of farmers to benefit from scientific progress. It is also noteworthy to refer to the second paragraph of article 15 of the covenant, which states that:" the steps to be taken by the states parties to the present covenant to achieve the full realization of this right shall include those necessary for the conservation, the development and the diffusion of science and culture."

Conclusion: Every human being has the right to have a job. Right to work as a fundamental concept is supported in international human rights. As was stressed, under the covenant, governments are obliged to ensure benefit from the rights, including the right to work, by using maximum resources and all appropriate measures. This obligation is closely related to article 11 of the covenant as the right of everyone to adequate standard of living for himself and his family. Without a job and money, allowing the enjoyment of other human rights, including live on welfare, is impossible. Offering exclusive and patented transgenic seeds by biotech seed companies and selling them to farmers with extensive control over the whole process is a matter that means affiliation of the farmers to these companies. In addition, the high cost of seeds, without the right to save seeds for planting next year, will exacerbate problems. As such, farmers have no choice but to sell their farms to large farmers and biotech companies.

To solve the conflict between the right to intellectual property and right to work in rural communities, governments must uphold, farmers, rights and civil needs within the framework of national and international law, and due to the legal limitations for neutral and unstable to access native plant species, they must develop a system to foster the breeding species. For example, by facilitating access to traditional agriculture seed varieties which are bred for food and agriculture, for commercial markets and sell their products, so that farmers encouraged continuing their activities.

In addition, local exchange of traditional seeds have great importance in supporting local seed breeding, especially in areas that local seed are not available in market. One method of achieving this goal is the establishment of community seed banks, like India and the Philippines, these association indigenous farmers share their seeds and other farmers, would find and buy their 
requirements. In fact farmers are the base of these associations. Public arrangements must guarantee appropriate availability of planting material at the right time and also sufficient diversity of seed and plant species.

These efforts help to increase the income of a large section of the population of vulnerable small farmers. The patent laws of many countries, including East Asian countries are also taken into account ethical considerations. For example, Japanese patent law considers that:" government must refrain to record inventions which seem to be contrary to public order, morality or public health." Under Patent law of the People, s Republic of China " an invention which is against the law of the state or social morality or public interest, patent license would not be granted." But in practice, these provisions are rarely invoked and legal literature in this area is very poor. Because of the absence of fair legal procedure, there is a risk that farmers would be marginalized.

\section{Thus the following suggestions are noteworthy to solve the problems:}

1. The leaders of the rich nations must not ignore the implicit restrictions in the intellectual property in the way that development and technological achievement for the south makes difficult or even impossible: the need to adopt a policy of real practical benefit to the south.

2. World Intellectual Property Organization (WIPO), must begin a survey on social and legal impacts which causes from IPR of transgenic crops.

3. The Food and Agriculture Organization (FAO) and the UN Conference on Trade and Development ( UNCTAD), must begin to organize a cooperation with social movements, including trade unions, representatives of indigenous and traditional communities in the evaluation of IPR effects on the other fundamental human rights including the right to work and implications of technology transfer and the needs and interests of developing countries to provide practical solutions to the existing problems in rural communities and overcome the crisis.

\section{References:}

1. Kowalski S. Transgenic crops, Biotechnology, Ownership rights: what scientists need to know. The plant journal 2002; 31(4):407-421.

2. Abaidoo S. Globalization, Biotechnologization of agriculture and farmers. International journal of manpower 2000; 21(6): 481-491.

3. Kruft D. Impacts of Genetically Modified crops and seeds on farmers. Legal Research 2010; (100)97: 2-15.

4. Lam H. A new approach to resolve the right to work, ethical dilemma. Journal of Business Ethics2006 ; ( 2007$)$ 73:231-243. 
5. Hannum $H$. The status of the universal Declaration of Human Rights in National and International law. Georgia Journal of International and Comparative law1998; (70)25: 270-293.

6. Warner K D. Are Life Patents Ethical? Conflict between Catholic Social Teaching and Agricultural Biotechnology's Patent Regime. Journal of agricultural and environmental ethics2001; 14(3): 301-319.

7. Ymmin R. IPRs, Biotechnology and Food security Paper prepared for the "Globalization and the International Governance of Modern Biotechnology" project. 2004 http://www.gapresearch.org/governance/ FYIPRsfinal.pdf.

8. Fransen L. Integrating Socio-Economic Consideration in to Biosafety Decision. World Research Institute2005; 1-53.

9. Enriquez J. Genomics and the world's economy. Science2008;(290) 281: 925-940.

10.Tisdell C. Safety and social economic issues raised by modern biotechnology. International Journal of social economics2009; (30)24: 670 - 699.

\section{Conflict of Interest:}

-I declare no conflict of interest. Bahareh Heydari PhD in Human Rights, Aix-Marseille University, France Prof, Payame Nour University, Iran, 4/7/2014. 